\title{
Romanization and Beyond: Aqueducts and Their Multilayered Impact on Political and Urban Landscapes in Roman Asia Minor
}

\author{
Saskia Kerschbaum
}

\section{Aqueducts and Romanization ${ }^{1}-$ A Broad Field of Research}

"The boldness of the enterprise, the solidity of the execution, and the uses to which they were subservient, rank the aqueducts among the noblest monuments of Roman genius and power. (...)"2

That is how the great historian Edward Gibbon outlined his conception of the character of Roman aqueducts. In his opinion, the Roman genius domesticated nature through a sense of pragmatism and utilitarianism. His conviction that aqueducts can be considered a symbol of the genius and power of Rome still characterizes current research. Sitta von Reden and Christian Wieland wrote in 2015: "The superior hydraulics of the Romans also manifested their claim to political leadership over the entire Mediterranean region."3 Aqueducts also stood for a certain Roman habitus, as Brent D. Shaw pointed out: Aqueducts can be seen as "symbols and devices useful for promoting a certain Roman

1 For a discussion and definition of the term 'Romanization' see below part 3 of this paper. If not otherwise indicated, all translations are my own.

2 E. Gibbon, The History of the Decline and Fall of the Roman Empire I (London 1897), 47.

3 S. von Reden and C. Wieland, 'Zur Einführung: Wasser - Alltagsbedarf, Ingenieurskunst und Repräsentation zwischen Antike und Neuzeit', in S. von Reden and C. Wieland (eds.), Wasser. Alltagsbedarf, Ingenieurskunst und Repräsentation zwischen Antike und Neuzeit (Göttingen 2015), 9-26, esp. 19 (quote translated from German). The discussion about development, function, technology, external impact as well as perception among the population is primarily focused on Rome. Accordingly Rome forms the frame of reference for the studies on water supply as an aspect of 'Romanization', see inter alia E. van Deman, The Building of Roman Aqueducts (Washington 1934); T. Ashby, Aqueducts of ancient Rome (Oxford 1935); G. De Kleijn, The Water Supply of Ancient Rome: City Area, Water, and Population (Leiden 2001). A detailed study of the administration is offered by M. Hainzmann, Untersuchungen zur Geschichte und Verwaltung der stadtrömischen Wasserleitungen (Wien 1975) and especially by many meritorious contributions of Christer Bruun, such as C. Bruun, The Water Supply of Ancient Rome. A Study of Roman Imperial Administration (Helsinki 1991). 
style of life in urban centres, whose élites aspired to be 'Roman'”. ${ }^{4}$ Following him, building aqueducts needs to be taken as a conscious attempt of municipal elites to imitate a superior urban and pronounced Roman lifestyle, which expressed itself not only in the building of aqueducts but also in an intensified bathing habit. This interpretation goes hand in hand with the widespread assumption that in order to be Roman a city needed a basic ensemble of different public buildings, for example baths and aqueducts. In 1998, Kathryn Lomas investigated the influence of Roman expansion since the 2nd century BCE on the transformation of Italian urban topography. According to Lomas, the construction of amphitheatres, temples of the imperial cult and baths can be seen as a reaction to Roman presence. ${ }^{5}$ Engelbert Winter even called aqueducts "cultural symbols", which in his opinion contributed to the "political and cultural standardization of the Roman Empire". 6

Different actors were held responsible for being the driving force of Romanization by building, financing or advertising aqueducts. Especially the Roman emperors are usually thought to be the most active builders in the Roman Empire. Engelbert Winter, for example, described aqueducts as "preferred objects of imperial welfare" because they were excellently suited to legitimize and publicly staging power. Furthermore, they were so expensive that only the emperors would be considered as builders anyway. ${ }^{7}$ As exponents of imperial power, especially the governors were also thought to be an important multiplier for the dissemination of Roman culture and way of life. ${ }^{8}$

4 B.D. Shaw, 'The noblest monuments and the smallest things: wells, walls and aqueducts in the making of Roman Africa', in A.T. Hodge (ed.), Future currents in aqueduct studies (Leeds 1991), 63-91.

5 K. Lomas, 'Roman Imperialism and the City in Italy', in R. Laurence and J. Berry (eds.), Cultural Identity in the Roman Empire (London and New York 1998), 64-78, esp. 78.

6 E. Winter, Staatliche Baupolitik und Baufürsorge in den römischen Provinzen des kaiserzeitlichen Kleinasien (Bonn 1996), 53 (quote translated from German).

7 Winter 1996, op. cit. (n. 6), 53 .

8 The scope of activities and the actual involvement of the governors regarding the building, financing and distribution of aqueducts cannot be discussed in detail here. They mostly acted on imperial behalf and represented the imperial authority in the provinces, see for example C. Schuler, 'Fernwasserleitungen und römische Administration im griechischen Osten', in A. Kolb (ed.) Infrastruktur und Herrschaftsorganisation im Imperium Romanum. Herrschaftsstrukturen und Herrschaftspraxis III, Akten der Tagung in Zürich, 19.-20.10. 2012 (Zurich 2014), 103-121, who presents the establishment of the province Lycia as a case study for a coordinated building program implemented jointly by governors and emperors. 
This short overview over the positions of modern research demonstrates a strong connection between aqueducts and Romanization and has already touched on the most important questions and aspects that will be discussed in this article, using Asia Minor as a case study.

Firstly, those responsible for the financing and distribution of aqueducts in Asia Minor and their potential reasons need to be detected. Did the Roman emperors and their governors, as often postulated in modern research, really use the construction of aqueducts as a demonstration of power and domination in the provinces, consciously pursuing a homogenous building policy by equipping the provinces with an ensemble of typically Roman buildings? Alternatively, did the cities themselves play a major role in the building of aqueducts? Answering these questions will also clarify the importance of the Roman presence for the development of a new water infrastructure, including not only aqueducts, but also public baths, toilets, nymphaea or artificial channels adorning new and monumentalized cityscapes. Second, the concept of Romanization, as it is used in relation to public infrastructure, should be defined. Based on this, the symbolic language of the aqueducts, i.e. their cultural code, is to be derived and examined for special Roman connotations. ${ }^{10}$ The cultural code will help to understand, why different groups and persons were active in building aqueducts and if their often postulated Roman-ness was pronouncedly used to justify these activities.

In doing so, the Roman impact on aqueducts in imperial Asia Minor will be analyzed in two different categories, aiming to clarify the importance of Rome for the building of aqueducts, counterbalancing it with the role of the cities and their interest for this new water infrastructure.

Before the arrival of Rome, aqueducts were a rarity in Asia Minor, although a large part of the necessary technology has already been developed in Hellenistic

For a short definition of the concept of an imperial building policy, see especially Winter 1996, op. cit. (n. 6), 3-5 and M. Horster, Bauinschriften römischer Kaiser. Untersuchungen zur Inschriftenpraxis und Bautätigkeit in Städten des westlichen Imperium Romanum in der Zeit des Principates (Stuttgart 2001), 250.

10 The term 'cultural code' should be broadly defined as a set of symbols, expectations or normative conventions, which were connected to aqueducts. For a more detailed discussion see chapter three below. 
times. ${ }^{11}$ Only few cities, like Pergamon or Ephesos built aqueducts, ${ }^{12}$ while most of the cities were dependent on rainwater or wells. The reason for this preference can probably be found in the unstable political landscapes of Hellenistic Asia Minor. The above-ground structures of aqueducts could easily be destroyed by enemies, who intended to interrupt the water supply of a city. ${ }^{13}$ Only the Romans were able to establish a long-lasting peace, the famed pax Romana. ${ }^{14}$

Proceeding chronologically, the Aqua Iulia and the Aqua Throessitica in Ephesos are among the oldest aqueducts built with imperial participation. While the construction of the Aqua Iulia is only preserved by a fragmentary inscription, ${ }^{15}$ we know a little more about the Aqua Throessitica: The pipeline was probably financed by Augustus and Tiberius and built under the

11 M. Lewis, 'The Hellenistic Period', in Ö. Wikander (ed.), Handbook of Ancient Water Technology (Leiden 2000), 631-648 about the development of innovative water technologies under the Hellenistic monarchies. The Romans advanced hydraulic engineering technology mainly through the invention of waterproof plaster and cement, materials that supported the building of overground structures like arches and bridges, see D. Kek, Der römische Aquädukt als Bautypus und Repräsentationsarchitektur (Münster 1996), 71-77.

12 For Ephesos see the following pages. Probably under the reign of Eumenes II in Pergamon, one of the most impressive aqueducts in Asia Minor, the so-called Madradağ-aqueduct, was built. Its siphon was made of massive lead pipes, bringing water to the acropolis, which was $200 \mathrm{~m}$ higher than ground level. Only lead pipes could resist the high water pressure, a knowledge and technique that was probably developed by Pergamenian water engineers, see especially G. Garbrecht, 'Die Wasserversorgung des antiken Pergamon', in Frontinus-Gesellschaft e.V. (ed.), Die Wasserversorgung antiker Städte. Pergamon, Recht/ Verwaltung, Brunnen/Nymphäen, Bauelemente (Mainz 1987), 11-49.

13 The destruction of urban water supply was a wide-spread and often effective strategy: The Athenians destroyed the pipelines of Syracuse during their occupation of Sicily in the fifth century BCE, see Th. 10o.6.

14 The idea of pax Romana became soon an important aspect of imperial representation, see e.g. J. Bleicken, Augustus. Eine Biographie (Berlin 1998), 512-518 and St. Mitchell, Cremna in Pisidia. An Ancient City in Peace and War (London 1995), 216 about the importance of a stable political environment for the building of aqueducts.

15 IK Ephesos 12, 401. The Aqua Iulia probably served to supply the port area, but its exact route is not yet known, see Ü. Öziş and A. Atalay, 'Fernwasserleitungen von Ephesos', in H. Friesinger and F. Krinzinger (eds.), 100 Jahre Österreichische Forschungen in Ephesos (Wien 1999), 407-409. 
supervision of Gaius Sextilius Pollio, a Roman knight, and his son, Pollio. ${ }^{16}$ Both aqueducts used nearby springs and were less than 10 kilometres long. ${ }^{17}$

An unusual inscription from Lycian Patara reports necessary reparation works in detail. ${ }^{18} \mathrm{~A}$ pressure section of the pipeline had been destroyed by a series of earthquakes in Neronian times and now it had to be repaired at great

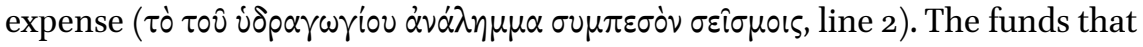
were used for this purpose came from the levied poll tax as well as from funds

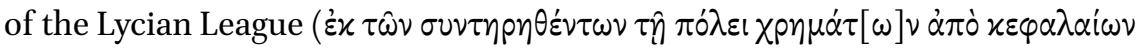

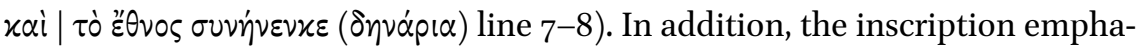

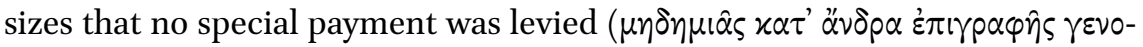
$\mu \varepsilon \dot{\varepsilon} \eta \varsigma$, line 9), a practice that was customary at that time for financing large buildings in Lycia. ${ }^{19}$ The complex financing model, which was only necessary for a single pressure section, demonstrates the high costs associated with the construction and maintenance of technically complex pipelines. These payments could not be made out of the usual public revenues, as the following example demonstrates.

Aphrodisias exchanged four letters with the Emperor Hadrian about the financing of a new aqueduct. ${ }^{20}$ Letter three contains the emperor's reply to a previous letter: Hadrian confirms the use of funds that were intended for

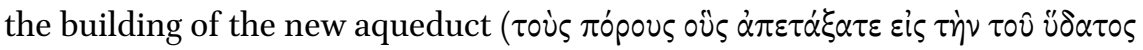

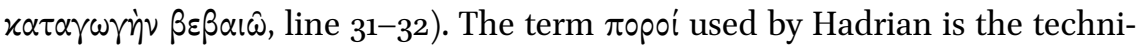
cal term for the city's finances, so the funds can be precisely identified. ${ }^{21} \mathrm{He}$

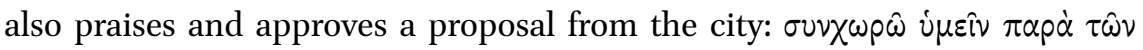

16 IK Ephesos 12, 402: Imp(erator) Caesar Aug(ustus) et Ti(berius) | Caesar Aug(usti)f(ilius) | aquam Throessiticam | induxerunt curam | agentibus $C$ (aio) Sextilio $P($ ublii)f(ilio) Pollione $\mid$

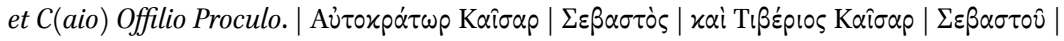

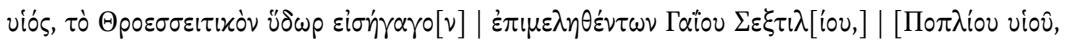

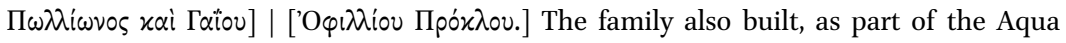
Throessitica, an aqueduct bridge out of their own funds see figure ns. 8.2 and 8.3.

17 G. Wiplinger, 'Neue Ergebnisse zur Wasserversorgung in Ephesos', in G. Wiplinger (ed.), De Aquaeductu atque Aqua Urbium Lyciae Pamphyliae, Pisidiae. The Legacy of Sextus Julius Frontinus (Leuven 2016), 313-329.

18 See the commented and translated (German) edition from Schuler 2014, op. cit. (n. 8), 109-110 and figure n. 8.1 showing the inscription in situ above on of two openings in the supporting wall of the siphon. A counterpart with the same text is placed on the other side above the second opening and shows that right-hand traffic was preferred in Roman times.

19 Schuler 2014, op. cit. (n. 8), 111.

20 The best edition of the texts is offered by J. Reynolds, 'New letters from Hadrian to Aphrodisias: trials, taxes, gladiators and an aqueduct', JRA 13 (2000), $5^{-20}$, with the transcribed Greek text on page 9 .

21 Liddell \& Scott s.v. Пopoí, 1450-1451. 


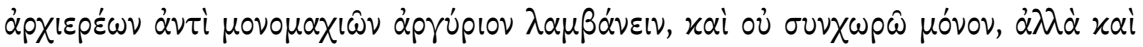
$\dot{\varepsilon} \pi \alpha \omega \omega \hat{\omega} \tau \dot{\eta} \nu ~ \gamma \nu \omega ́ \mu \eta \nu$ (line $36-37$ ).

At the end the city was given authority to choose the $\dot{\varepsilon} \pi \mu \varepsilon \lambda \eta \tau \alpha$ i who were to take care of the aqueduct and was referred to his procurator Pompeius Severus (line 38-41) for further questions. ${ }^{22}$

Communication can probably be reconstructed as follows: The city asked the proconsul or the emperor himself for help with the construction of an aqueduct and then had to submit a financing plan. The plan was to draw on the financial reserves of Aphrodisias and on diverse additional funds from the high priests. Hadrian agreed to this plan and offered further organizational help, but not the financial means the city might have hoped for. ${ }^{23}$ Joyce Reynolds assumes that the financing of the aqueduct from funds that were actually intended for gladiatorial games was not popular and therefore the emperor's approval had to be obtained. ${ }^{24}$ Kathleen Coleman suggested a different interpretation: She assumes that the high priests preferred to finance the aqueduct rather than the games, since the costs were lower and easier to calculate. ${ }^{25}$ According to her Hadrian supported the priests with this financing plan and at the same time expanded the possible pool of candidates by reducing the costs of the liturgy.

In my opinion, the following explanation appears more plausible: The local high priests had invested a fixed amount of money either out of their official budget or from their own funds for monomachies, but the city wanted to redirect these funds for the construction of the aqueduct. The organization of monomachies was such a popular benefaction among high priests that

22 The role of the proconsul remains unclear, but we know from other examples that it was in his responsibility to provide engineers or other specialists or general legal and organizational help for the building process, see A.R. Commito, 'The Aqueducts of Aphrodisias', in C. Ratté and P.D. de Staebler (eds.), Aphrodisias V, The Aphrodisias Regional Survey (Darmstadt and Mainz 2012), 291. The most famous example for organizational and technical help of the governors is the case of the librator Nonius Datus in the 2nd century CE. The soldier was responsible for the building of a tunnel in the city of Saldae (Mauretania), but retired while construction was still in process. The governor Titus Varius Clemens had to ask his superior to get Datus back to the building site, because the workers had made serious mistakes endangering the whole project. Datus finished the tunnel and recorded everything proudly on his grave stele, see $C I L$ VIII 2728 and S. Cuomo, 'A Roman engineer's tales', JRS 101 (2011), 143-165 with the latest discussion.

23 According to Reynolds 200o, op. cit. (n. 20), 17 the city was not obliged to get the authorization of the emperor for its plans, but hoped for help for this large project.

24 Reynolds 200o, op. cit. (n. 20), 19.

25 K. Coleman, 'Exchanging gladiators for an aqueduct at Aphrodisias (SEG 50, 1096)', $\mathrm{ActaCl}_{51}$ (2008), 34. 


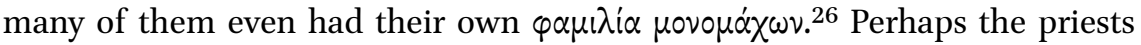
had turned to the city to protest against the redirection of these funds, which they would rather prefer to invest in prestigious games than in an insignificant water pipeline. The city had probably written to the governor on this matter, who involved the emperor. In addition, gladiatorial games were part of the imperial cult and therefore required permission from the emperor if they were to be reduced or cancelled. ${ }^{27}$

While the inscriptions seldom mention precise sums, the literary sources are much more informative. That the building of an aqueduct in fact consumed high sums, tells us, for example, Philostrat with a short story about Herodes Atticus. When Herodes Atticus came to Alexandria Troas in 134/135 CE, he saw that the city was missing any kind of water infrastructure and asked Emperor Hadrian to give him three million drachms to build an aqueduct, baths and a fountain. But as the project became much more expensive than planned and Herodes had to ask for an additional financing of four million drachms, the procurator of Asia Minor complained that the levies of 500 cities had to be diverted for a single project. ${ }^{28}$ Although it is quite probable that the argumentation of the proconsul contains a literary exaggeration, ${ }^{29}$ the episode demonstrates very nicely the complexity of financing an aqueduct and the sums involved. Moreover, it is noteworthy that the emperor used a redistribution of taxes for this project and not his own funds. The most important link between the province and the emperor were the governors. The letters of Pliny, who was on an imperial mission in Bithynia et Pontus under Traian, show that the governors were able to function as initiators of water infrastructure. ${ }^{30}$ In addition, they were able to act as local contacts and supervisors of construction measures, but they never financed an aqueduct out of their own pocket or out of imperial funds.

26 M. Carter, 'Archiereis and Asiarchs: A Gladiatorial Perspective', Greek, Roman and Byzantine Studies 44 (2004), 66-68.

27 D. Campanile, 'Noterelle ai nuovi documenti da Afrodisia', ZPE 135 (2001), 136-138, esp. 138.

28 Philostr. $V S$ 2.1.3. The refusal of the procurator referred not to the aqueduct, but to a $x p \eta \eta \eta \eta$ So perhaps he was just no longer willing to finance the ending point of the pipeline in form of a fountain out of public funds.

29 The number of 500 cities was used as a synonym for the whole province of Asia, see for example J. BJ 2.16.4 and Ap.Ty. Ep. $5^{8 .}$

30 Pliny was legatus pro praetore consulari potestate in the province Bithynia et Pontus in $109 \mathrm{CE}$ to control the civic finances. During this time, he also took care of several water infrastructure projects, for which he always sought to obtain the emperor's permission, see P. Wehmann, Der jüngere Plinius und sein Kaiser. Die Statthalterschaft Plinius des Jüngeren zwischen Selbständigkeit und Abhängigkeit (Hamburg 2014), 81-86. 
The evidence shows clearly that the emperors were only financially active to a very limited extent and focused their commitment on important conventus cities, like Ephesos or Patara, or prestigious colonies. The emperors were thus much more often involved in organizational matters. They were responsible for the redistribution of funds, the provision of specialists like engineers or architects and they gave advice and assistance in organizational and legal matters. Moreover, they acted mostly at request of the governors or in special situations like earthquakes. Therefore, a comprehensive and planned imperial building policy seems non-existent.

In fact, as will become clear in the following section, the low level of imperial commitment can be explained above all by the fact that the cities bore the main burden for the construction of long-distance water conduits. First of all, the cities were the main financiers of aqueduct construction. Rarely do we learn details of how the cities were able to cope with this exceptional financial burden. Otherwise, the building inscriptions only provide the general information that the cities acted as the institution responsible for the building. ${ }^{31}$ Financing also seems to play a lesser role in Pliny's letters, because Pliny usually only confirms to the emperor in very general terms that he is taking care of the financing or that something similar has already happened, such as for a new water pipe in Sinope or the covering of a canal in Amastris. ${ }^{32}$ In Traian's replies, who almost always approves the construction projects, financing hardly plays a role. Assuming a general solvency of the poleis, Pliny and his complaints about the cities of Asia Minor can be interpreted differently: In fact, they rather point out that the cities were in an excellent financial condition. Otherwise, Nicomedia would hardly have been able to waste 3.5 million sesterces on two unfinished aqueducts, or Nicaea 10 million sesterces on an unfinished theatre. ${ }^{33}$ Pliny actually mentions a concrete reason for this unnecessarily high expenditure of public money several times, namely not financial distress or civic mismanagement, but widespread corruption. ${ }^{34}$ This also

31 See W. Eck, 'Wasserbauten in den spanischen Provinzen Roms. Staatliche, städtische oder private Verantwortung für die Infrastruktur?', in T. Schattner and E. Valdéz Fernández (eds.), Wasserversorgung in Toledo und Wissensvermittlung von der Antike bis ins Mittelalter (Tübingen 2017), 316, who discusses the scarcity of sources regarding the public building activity and the role of the cities in context with water infrastructure, using the Spanish provinces as a case study.

Plin. epist. 10.9o; 98, ed. W. Williams, Correspondence with Traian from Bithynia, Epistles $X$ (Warminster 1990).

33 Plin. epist. 10.37 (Nicomedia); 39 (Nicaea).

34 Plin. epist. 10.17a.3 and 10.17b.2: videntur enim non mediocres pecuniae posse revocari a curatoribus operum, si mensurae fideliter agantur. 
shows us that there can be no question of a financial misery of the cities in the imperial era, often postulated in modern research. ${ }^{35}$

Moreover, the cities were the only authorities able to support and control the construction and expansion of their water infrastructure. The water system as a whole was a fragile balance of inflow and outflow, so that the construction of new baths or magnificent fountains and the allocation of a private water supply in the countryside and in the city had to be precisely regulated. The public administration had a close eye on the capacity of its water system. In Rome, the senators decided in 11 BCE not to build new wells because the aqueducts could not cope with additional outflow. ${ }^{36}$ In Asia Minor, too, the cities kept precise lists of their existing water structures: In Erythrai, a list of all roads including the sewers running along them was kept as early as the 4 th century BCE; ${ }^{37}$ in Sardeis, a list of wells was established in the 3 rd century CE, which precisely identified the wells on the basis of various topographical additions. Moreover, the wells were classified by their capacity (100-1700 litres). ${ }^{38}$ This strictly balanced input-output system also meant that potential benefactors had to coordinate their donations, like for example baths, with the municipal bodies.

\section{3 \\ What Is Roman about Aqueducts? - Water Infrastructure as an Important Part of Civic Identity}

With this in mind we can now turn to the second part, the so-called cultural code or the symbolic language in connection with aqueducts. As was demonstrated at the beginning, modern research is very focused on the Roman-ness of aqueducts. The term 'Romanization', which is often used in this context, was not only often discussed in modern research, but also used in the most diverse connotations and different facets, to the point where its possible benefits were called into question in general..$^{39}$ Criticisms are mostly the given point of view (Rome-Province), the thereby implicitly assumed superiority of Roman

35 See, for instance, Winter 1996, op. cit. (n. 6), 6o. Cf. H. Schwarz, Soll oder Haben? Die Finanzwirtschaft kleinasiatischer Städte in der römischen Kaiserzeit am Beispiel von Bithynien, Lykien und Ephesos (29 v. Chr.-284 n. Chr.) (Bonn 2001).

$36 \quad$ Frontin. aq. 104.1.

$37 \quad$ IK Erythrai 151.

38 W.H. Buckler and D.M. Robinson, Sardis VII: Part I, Greek and Latin Inscriptions (Leiden 1932), 38-39, n. 17 .

39 G. Alföldy, 'Romanisation-Grundbegriff oder Fehlgriff? Überlegungen zum gegenwärtigen Stand der Erforschung von Integrationsprozessen im römischen Weltreich', in Z. Visy (ed.), Limes XIX, Proceedings of XIXth International Congress of Roman Frontier Studies held in Pécs, Hungary, September 2003 (Pécs 2005), 25-57, with a concise summary. 
culture over non-Roman ways of life, the disregard of cultural interactions on an equal level and the ignorance of the decisive actors. ${ }^{40}$ First, it should be noted that 'Romanization' is both a process and a result of a process that, in a broader sense, involves the integration of a particular group of people subject to Roman rule and, consequently, the transformation of their living conditions and their acceptance of the Roman presence. In the meantime, the consensus is that this process must be understood as bilateral, i.e. as the offer and acceptance of a "range of objects, beliefs and practices that were characteristic of people who considered themselves to be and were widely acknowledged as Roman." ${ }^{\text {"1 }}$ At least the "expectation of the rulers in Rome that their subjects (...) integrated themselves into the community of res publica" can be assumed, giving a frame for the idea of Romanization. ${ }^{42}$ This acceptance had to come above all from the local elites, who had to reconcile their own urban cultural identity with the Roman presence.

Among the various facets that Romanization can assume, the question of the extent to which buildings and certain architectural forms were perceived as typically Roman is particularly relevant in the context of this article. Since these were ultimately built with a purpose and in connection with social practices or a social habitus, the form of construction cannot be separated from its socio-cutural meaning. Stefan Burmeister and Nils Müller-Scheeßel called the idea of the symbolic language of a building 'cultural code', a term that will be used for the analysis later. ${ }^{43}$ Felix Pirson in particular postulated that it was precisely this adoption of the symbolic language associated with a building that could make the degree of Romanization measurable. ${ }^{44}$

The strongly Rom-centered perspective regarding aqueducts is, of course, not solely due to Edward Gibbon, but has its origins in fact in literary sources. One of the most important and most cited testimonies is the curator aquarum

40 See for example M. Meyer (ed.), Neue Zeiten - Neue Sitten. Zur Rezeption und Integration italischen Kulturguts in Kleinasien (Wien 2007), 15-16.

41 G. Woolf, Becoming Roman. The Origins of Provincial Civilisation in Gaul (Cambridge 1998), 11.

42 Alföldy 2005, op. cit. (n. 39), 32. About the Roman way of life see also R. MacMullen, Romanization in the time of Augustus (New Haven and London 2000), 125.

43 S. Burmeister and N. Müller-Scheeßel, 'Innovation as multi-faceted social process: an outline', in S. Burmeister et al. (eds.), Metal Matters, Innovative Technologies and Social Change in Prehistory and Antiquity (Rahden 2013), 4.

44 F. Pirson, 'Zusammenfassende Gedanken zur Bedeutung von Kulturkontakten als Auslöser architektonischer Innovation', in F. Pirson and U. Wulf-Rheidt (eds.), Austausch und Inspiration. Kulturkontakt als Impuls architektonischer Innovation. Kolloquium vom 28.-30.4.20o6 in Berlin anlässlich des 65. Geburtstags von Adolf Hoffmann (Mainz 2008), 312-319. 
Frontinus, who repeatedly praised the aqueducts as a Roman invention and symbol of Roman civilization..$^{45}$ Pliny the Older, too, is overwhelmed with admiration for the aqueducts. ${ }^{46}$ And Dionysios of Halicarnass writes that he

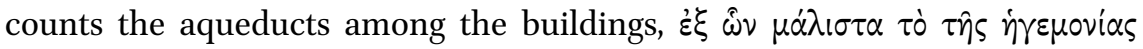
$\varepsilon \mu \varphi \alpha i v \varepsilon \tau \alpha l \mu \varepsilon^{\prime} \gamma \varepsilon \theta \circ$, "from which the hegemonia of the empire radiates out the most." ${ }^{\prime 7}$ While these statements might be explainable, because the authors' point of reference is usually the city of Rome with its nine large and impressive aqueducts, other literary sources are much more explicit in their differentiation between the Roman-ness and Greekness of buildings. One of the most famous quotes in this context is a short passage written by Cicero.

Atque etiam illae impensae meliores, muri, navalia, portus, aquarum ductus omniaque quae ad usum rei publicae pertinent, quamquam, quod praesens tamquam in manum datur, iucundius est, tamen haec in posterum gratiora. ${ }^{48}$

If expenditure is to be made, then in his opinion it is better invested in public infrastructure such as walls or aqueducts. While Cicero does not mention which buildings he considers to be worse than public buildings, this becomes clearer with Strabo:

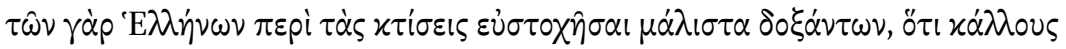

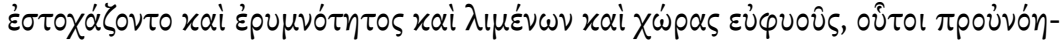

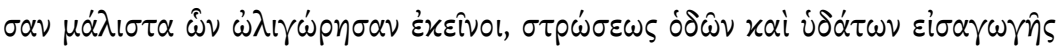

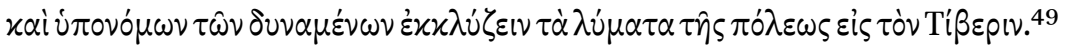

Strabo's short text is a prime example of the discourse on the discrepancy between the 'beautiful' buildings of the Greeks and the practical functionality of

45 Frontin. Aqu. 16; 88-89; 119. (magnitudinis Romani imperii).

46 Plin. nat. 36.121: vera aestimatione invecta miracula.

47 D.H. 3.67.5.

48 Cic. off. 2.6o: These expenses are again better justified when they are made for walls, docks, harbours, aqueducts, and all those works, which are of use for the community. There is, to be sure, more of present satisfaction in what is handed out [meaning monetary donations]; nevertheless these [public improvements] win us greater gratitude from future generations.

49 Str. 5.3.8: The Greek cities are thought to have flourished mainly on account of the fortunate choice made by their founders, in regard to the beauty and strength of their sites, their proximity to some port, and the beauty of the country. They [the Romans] were more concerned over matters that had received but little attention from the Greeks, such as paving their roads, constructing aqueducts, and sewers to convey the sewage of the city into the Tiber. 
Roman engineering buildings. Both writers underline not only the Roman-ness but the general importance of public infrastructure because it serves utilitas publica, one of the most important keywords regarding the cultural code of aqueducts.

For Vitruvius, apart from firmitas and venustas, utilitas was one of the three most important criteria of Roman architecture. ${ }^{50}$ Among the usual public buildings were streets and walls, as well as water pipes. Their construction was so highly regarded that Sueton, according to his own statements, refrained from blaming Emperor Claudius for his generally low construction activity, because he had financed two aqueducts. ${ }^{51}$ The emperors were also subject to particularly harsh criticism when they did not fulfil their duty of care for the public buildings, such as Nero, who had given up parts of the Roman Aqua Claudia, or Caligula, who destroyed the Aqua Virgo. ${ }^{52}$ Buildings that served the public good were not only highly regarded, in addition to their utilitas publica, further characteristics were associated with aqueducts.

A frequently used feature is salubritas. Pliny, for example, complains that there is an uncovered canal running through Amastris, which endangers the health of the whole city because it is dirty and smells disgusting; therefore it must be covered..$^{53}$ The late antique poet Rutilius Namatianus emphasized not only the quality of fresh and therefore healthy water, but also the climatic effect, namely the cooling air, which emanated from the water that was available everywhere and that cooled down the hot city air of Rome. ${ }^{54}$ Accordingly, the Aqua Marcia was considered the most important of all aqueducts because, thanks to its pure water, it contributed to Rome's health. ${ }^{55}$ The idea of a better health resulting from of the availability of fresh water is also present in inscriptions: a benefactor from the Italian city Interamna Lirenas underlined that he gave healthy water, aqua salutaris, to his hometown. ${ }^{56}$ Salubritas is mostly

$50 \quad$ Vitr. 1.2.3. For the social and political relevance of the concept of utilitas publica see especially M. Jehne and C. Lundgreen (eds.), Gemeinsinn und Gemeinwohl in der römischen Antike (Stuttgart 2013).

$51 \quad$ Suet. Claud. 20.1.

52 Frontin. aq. 76.6-7; Tac. Ann. 14.22.4 (Nero); CIL VI 1252 (Claudius restoring the Aqua Virgo, destroyed by Caligula).

53 Plin. epist. 10.98.

54 Rut. Nam. 1.101-106.

55 Plin. nat. 31.41-42, using publica salus as synonym for water in the same context: clarissimum aquarum omnium in toto orbe frigoris salubritatisque palma praeconio urbis Marcia est inter reliqua deum munera urbi tributa (31.41).

$5^{6} \quad$ CIL X $5411=$ Dessau 578 o. See also $C I L$ VIII 1828. 
accompanied by pulchritudo or decor of the buildings. ${ }^{57}$ Rutilius Namatianus compares the arches of the aqueducts in their height and lightness even with a rainbow. ${ }^{58}$ It is possible to see these concepts implemented in the building structure itself: The above-ground sections were designed according to deliberate aesthetic criteria, for example by covering them with marble, as can be seen at the above-mentioned Pollio Bridge, a part of the Ephesian Aqua Throessitica. Another alternative was the use of alternating brick patterns, as it was practiced in Merida (Spain). ${ }^{59}$ While these characteristics of aqueducts cannot be associated with Romanization or civic identity and civic pride only, but were used by all actors involved in aqueduct building, the following section will demonstrate, how and why the cities were so proud of building a new water infrastructure and that they were ready to invest considerable financial and human resources into it.

The longest passage regarding this topic has been handed down in the Antiochikos of Libanios, an eulogium to his hometown Antioch on the Orontes. After underlining that the city did not have to use water springs from the territory of another city, because there is enough water in the surroundings, Libanios writes:

Now our chief advantage is that our city has an abundant water supply. There could possibly be disagreement on other matters, but when we mention our water supply, everyone must yield (...) If anyone has the financial means to build another bath in addition to the existing ones, he can do so confidently and does not need to worry about the water. And he does not need to fear that, when he has embellished it beautifully, it could be called 'dry as a bone', because the nymphs are missing (...) So we have no fights around our public fountains as to who will draw water before his neighbour, which is a nuisance to many a wealthy town. ${ }^{60}$

See A. Scheithauer, Kaiserliche Bautätigkeit in Rom. Das Echo in der antiken Literatur

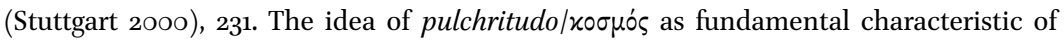
a city in imperial Asia Minor, which included much more than a fitting urban building ensemble, is discussed in length by I. Maupai, Die Macht der Schönheit. Untersuchungen zu einem Aspekt des Selbstverständnisses und der Selbstdarstellung griechischer Städte in der römischen Kaiserzeit (Bonn 2003).

58 Rut. Nam. 1.97-99; quid loquar aerio pendetes fornice rivos / qua vix imbriferes tolleret Iris aquas / hos potius dicas crevisse in sidera montes. The indication of height was often used for the description of the aesthetics of public buildings, but sometimes exaggerated and not always reliable, see Scheithauer 200o, op. cit. (n. 57), 223-224.

59 See figures n. 8.2-3 (Ephesos) and n. 8.4 (Merida).

6o Libanios' vivid description of how people crowded around wells and could become violent is not exaggerated. Theophanes reports in his chronicle that in November $5^{62} \mathrm{CE}$ 
There they push and jostle around the fountain and there is weeping and wailing when bowls are broken and at the injuries received around the springs. (...) Besides, with regard to the purity of the water, you could make a fair test, if you were to fill a swimming pool and then stop its swirls. You would think it to be empty for the floor of the pool stands out so clearly under the water. ${ }^{61}$

What is reflected here is the pride of a citizen for the water infrastructure of his hometown, especially for the quantity and quality of the water. Libanios makes a clear difference between water for daily use and for luxurious buildings as baths, stressing the point that Antioch could boast with having enough water for both.

The fact that water remained a limited resource even during the imperial era despite improved technical possibilities is on the one hand often reflected in literary sources. Martial, for example, mocked the fact that water in Ravenna was more expensive than wine and that he therefore preferred the former. ${ }^{62}$ Sidonius Apollinaris' remark about the mud in the water reservoirs fits in with Martials comment. ${ }^{63}$ Horace also frequently complains about the fact that water in Aequum Tutivum, Canusium or Gnatia, for example, can only be obtained against payment, and wonders whether the bad water in Velia or Salernum is rainwater or well-water. ${ }^{64}$ It comes as no surprise then, that the image of quenching the thirst of a 'dry and thirsty city' was even used in inscriptions until late antiquity. ${ }^{65}$

On the other hand, water infrastructure soon advanced to become a substantial prerequisite for every city, as a much quoted bonmot of Pausanias proves:

a drought broke out in Constantinople and people at the wells were fighting so much for water that some of them died, AM 6055, ed. C. de Boor, Theophanis Chronographia (Princeton 1883), 237. See also the description by Malal. 425, 24-25.

61 Lib. Or.11. 244-248, according to the translation from G. Fatouros and T. Krischer, Libanios. Antiochikos (or.XI). Zur heidnischen Renaissance in der Spätantike (Wien and Berlin 1992). Archaeological finds show that Libanios' praise is close to reality, see H. Pamir, 'Water supplies of Antioch on the Orontes', Adalya 15 (2012), 33-64.

62 Mart. 3.56.

63 Sidon. 5.6.

64 Hor. sat. 1.5.88-91; Hor. epist. 1.15.15-16.

65 According to Procopius, Emperor Justinian saved the city of Constantinople by building an aqueduct and a cistern (Procop. Aed. 1.11.10-15). A honorary inscription for the comes Erythrios (5th century CE), who renovated the pipelines to the baths of Amisos, used the term $\dot{\delta} \delta \dot{\alpha} \tau \omega \nu \lambda i \psi \omega \nu$ (line 14), although the surroundings of the city are evidently rich of water resources, see C. Marek, 'Der Dank der Stadt an einen comes in Amisos unter Theodosius II', Chiron 30 (2000), 367-387. 


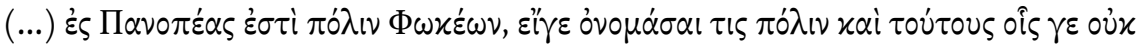

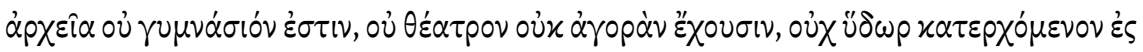
xpทं $\eta v .{ }^{66}$ The supply of drinking water should be part of the self-evident duties of a city, but this was not always the case as in Panopeus where no theater or gymnasium existed, not even water which would be falling into a fountain. Pausanias criticizes several cities that had succeeded in providing the necessary daily water, but not in providing their inhabitants with the convenience of bathing: In Hyampolis in Greece there was only one well for drinking water, for everything else the inhabitants had to use rain water; also in Peloponnesian Pellene one only had drinking wells and had to bath in rain water. ${ }^{67}$ According to a story written by Procop, the inhabitants of Dara in Mesopotamia even left the city, when the aqueduct had become inoperative because they would otherwise have died of thirst. ${ }^{68}$ Andrea Schmölder-Veit rightly notes that it was probably the upper class of Dara who left the city because they were no longer provided with a certain level of quality of life and comfort. ${ }^{69}$

Especially vivid is the connection between a good drinking water supply and urbanitas and poor water sources and cultural as well as technological backwardness in Ovids Tristia. He complained bitterly about his exile in Tomi: o quantum et quotiens non est numerare, beatum, non interdicta cui licet urbe frui. ${ }^{70}$ The Aqua Virgo is often enough at the center of admiration and is

66 Paus. 10.4.1. (...) to Panopeus, a city of the Phocians, if one can give the name of city to those who possess no local offices, no gymnasium, no theater, no market-place, no water descending to a fountain.

67 Paus. $10.35 .6 ; 7.27 .4$.

68 Procop. Aed. 2.3.24-26.

69 A. Schmölder-Veit, Brunnen in den Städten des westlichen römischen Reiches (Wiesbaden 2009), 32-33.

70 Ov. trist. 3.12.25-26. The concept of urbanitas has two important key components: architecture and lifestyle. To be attractive for its inhabitants a city had to offer a set of buildings, including public infrastructure, gymnasia etc. Only in a fitting and built-up surrounding urbanitas could be practiced, which meant an urban habitus, as Martial describes it: gestatio, fabulae, libelli, campus, porticus, umbra, virgo, thermae, Mart. 5.20.8-9. The connection of a built-up environment and an urban life style can also be observed in the term $\dot{\sigma} \sigma \varepsilon \hat{i} \sigma \varsigma$ itself, meaning not only 'urban', but also 'educated, beautiful'. Urbanitas gained importance in imperial times, when the cities instrumentalized their buildings, myths and history against other cities to fight for political and symbolic importance, see especially A. Scheithauer, Verfeinerte Lebensweise und gesteigertes Lebensgefühl im augusteischen Rom. Urbanitas mit den Augen Ovids gesehen (Frankfurt 2007), 11-32 and H.-J. Schalles, 'Urbis nostrae miracula. Qualitätskriterien urbaner Räume in antiken Schriftquellen', in J. Lipps, A. Busch and J. Griesbach (eds.), Urbanitas - urbane Qualitäten. Die antike Stadt als kulturelle Selbstverwirklichung (Heidelberg 2017), 17-38. 
regarded as a symbol for a dignified life. ${ }^{71}$ In Tomi, on the other hand, the water supply falls far short of Ovid's bearable standard: est in aqua dulci non invidiosa voluptas: aequoreo bibitur cum sale mixta palus. ${ }^{72}$ The water in Tomi is not only salty, but also brackish and interspersed with mud and does not even quench thirst, since there are no springs. ${ }^{73}$

The other way around was also possible: Villages could become cities by having a good water supply. In Constantinian times the vicus Orkistos in Phrygia asked the emperor to become a civitas and justified its petition by vividly describing its urban character. Part of its urbanitas was an urban building ensemble including baths and the fact that the city had an abundant water supply that could be used for baths and water mills. ${ }^{74}$

The arrival of Rome in the politically fragmented landscape of Hellenistic Asia Minor caused many deep changes in the daily life of its inhabitants. For many it opened up new chances as well. One was the widespread building of a new type of water infrastructure, supplying the cities with a new quantity and quality of water not only for daily needs, but also for luxurious commodities such as baths, lavish fountains, wells and toilets. The cities embraced this opportunity with stunning speed. Ephesos built its first Roman aqueduct probably with imperial help already under Augustus, the other metropoleis followed at the latest under Claudius. For the building of aqueducts, the cities had to spend and pool a great amount of financial and human resources, which they had to organize mostly without an additional imperial funding. Therefore, it comes as no surprise that the cities integrated the cultural code of the aqueducts - which might have had a Roman imprint at the beginning - soon into their civic identity. In doing so, the point of reference of the cultural code were

$71 \quad$ Ov. ars 3.38.5-6; Cassiod. var. 7.6.3; Mart. 7.32.11-12.

72 Ov. Pont. 2.7.73-74.

73 Ov. Pont. 3.1.17-18: nec tibi sunt fontes, laticis nisi paene marini, qui potus dubium sistat alatne sitim.

74 CIL III $35^{2}$ with the relevant comment edited by A. Chastagnol, 'Linscription constantinienne d'Orcistus', MEFRA 93 (1981), 381-416. See also C. Witschel, 'Sterbende Städte? Betrachtungen zum römischen Städtewesen in der Spätantike', in A. Lampen and A. Owzar (eds.), Schrumpfende Städte: ein Phänomen zwischen Antike und Moderne (Wien 2008), 17-78, esp. 29, with the noteworthy remark that Orkistos may not have owned all of these buildings, but made a probably fictional selection of those monuments, the city's elite thought would be standard for a city. 
exclusively the cities. Practical or economic aspects like a better water supply for agriculture and the surrounding villages did not play a role. As most of the cities were equipped with aqueducts in the 2nd century CE, an abundant water supply even became a necessary feature, as important as walls, streets, gymnasia or baths. If a city wanted to call itself a (true) city and to display a certain urbanitas, at least a fountain and a bath, supplied by an aqueduct, was a basic prerequisite for its inhabitants.

Without the presence of the Romans and their impact on the political landscape of Hellenistic Asia Minor, the building and distribution of aqueducts would have been impossible. It was exactly the combination of economically flourishing cities and a strong Roman super-structure in form of provinces, guaranteeing peace, prosperity and fair jurisdiction executed by the governors that led to the sweeping success of this new kind of water supply system.

Let's conclude with some remarks about the connection of Romanization and water infrastructure in general. In contrast to what most of the researchers claimed, this paper aimed to clarify that the building of aqueducts was not instrumentalized by Roman authorities to legitimize their rule, but rather a purely civic phenomenon. These aqueducts served not only public, but also private needs. The local elites took the opportunity to introduce a new category of representation: sophisticated and lavishly decorated private baths, supplied by side branch of the urban aqueduct, for which they probably paid a fee. This kind of water-related representation, including other water-consuming features such as fountains, pools, canals, ornamental ponds and gardens, might have had its roots in Hellenism, but its origin, as Inge Uytterhoeven made clear, were not the Hellenistic monarchies, but Rome. ${ }^{75}$ The elites therefore consciously adopted and imitated Roman social behavior, trying to practice a Roman lifestyle by bathing more urbico, as a famous inscription tells us: In his praediis Aureliae Faustinianae balineus lavatur more urbico et omnis humanitas praestatur. $^{76}$

75 I. Uytterhoeven, 'A private piece of nature: water display as part of an artificial natural environment in Roman and late antique elite houses of Asia Minor', in G. Wiplinger (ed.) De Aquaeductu atque Aqua Urbium Lyciae Pamphyliae Pisidiae. The Legacy of Sextus Julius Frontinus (Leuven 2016), 227-242, esp. 236.

76 ILS 5720 (Caesarina, 2nd/3rd century CE). On the properties of Aurelia Faustiniana there is a bath, where one takes a bath in the manner of the city and every refinement is guaranteed. 


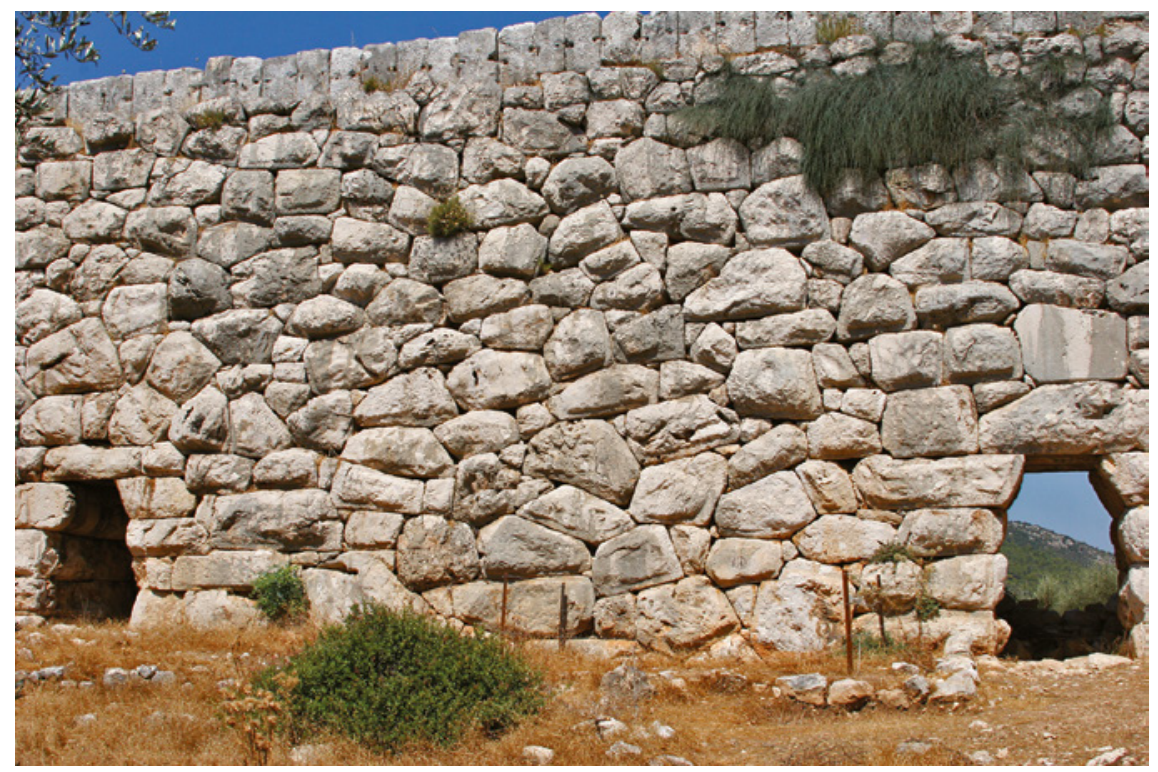

FIGURE 8.1 Delikkemer. Aqueduct bridge near Lycian Patara PHOTO C. SCHULER, KOMMISSION FÜR ALTE GESCHICHTE UND EPIGRAPHIK

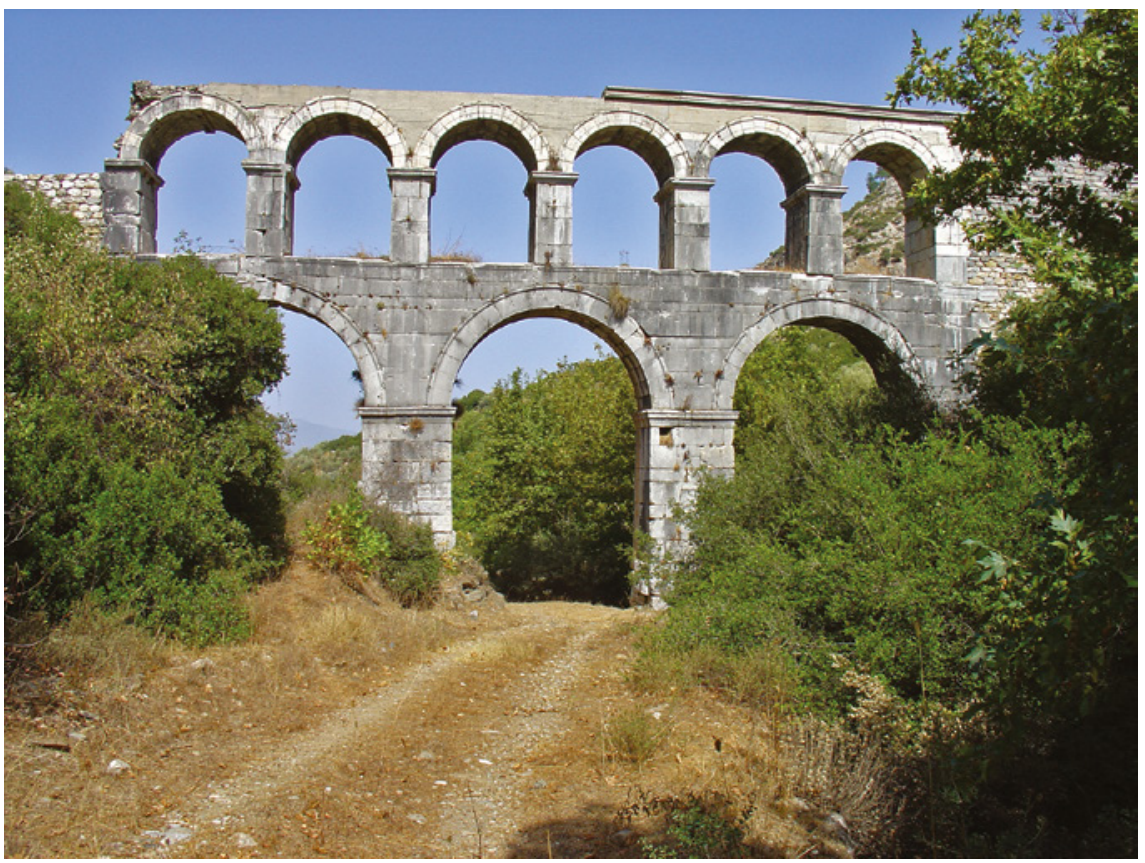

FIgURE 8.2 Section of the Aqua Throessitica, Ephesos

PHOTO G. WIPLINGER, (C) ÖSTERREICHISCHES ARCHÄOLOGISCHES INSTITUT AN DER ÖSTERREICHISCHEN AKADEMIE DER WISSENSCHAFTEN 


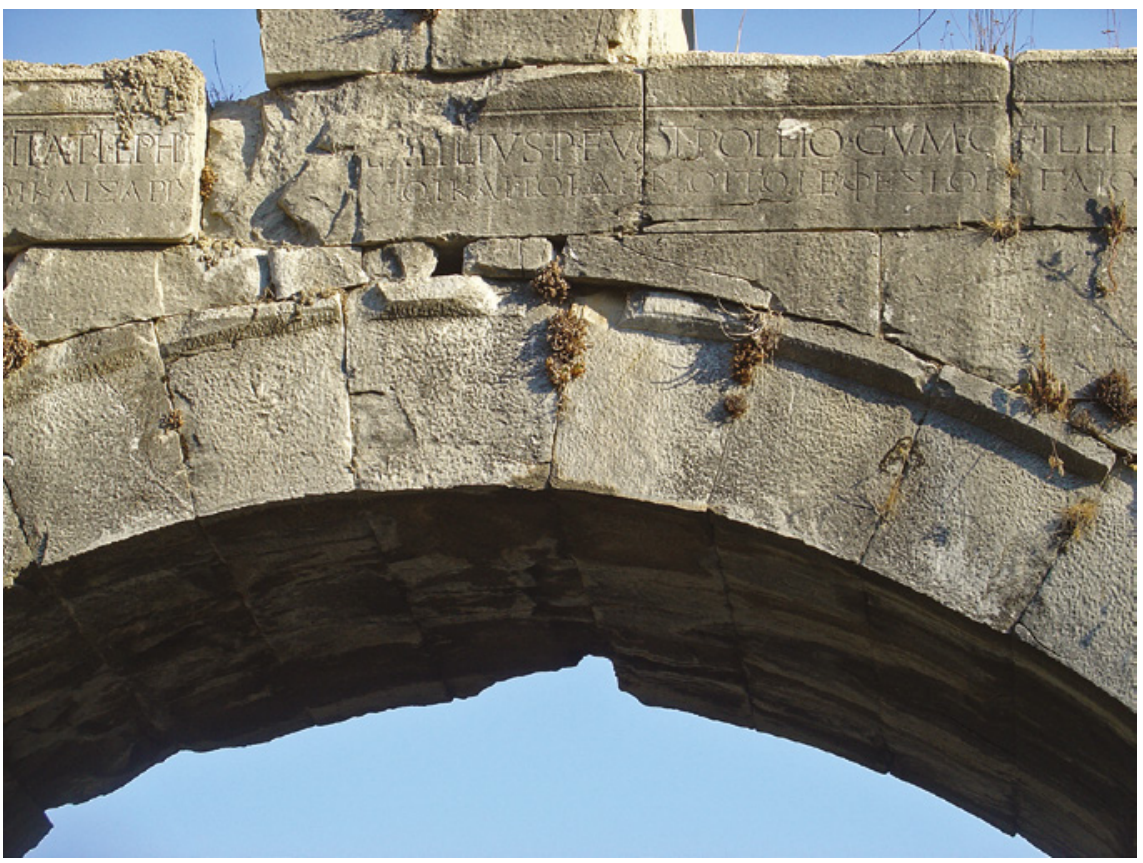

FIGURE 8.3 Detail with inscription (IK Ephesos 12, 402) of a section of the Aqua Throessitica, Ephesos

PHOTO G. WIPLINGER, (C) ÖSTERREICHISCHES ARCHÄOLOGISCHES INSTITUT AN DER ÖSTERREICHISCHEN AKADEMIE DER WISSENSCHAFTEN

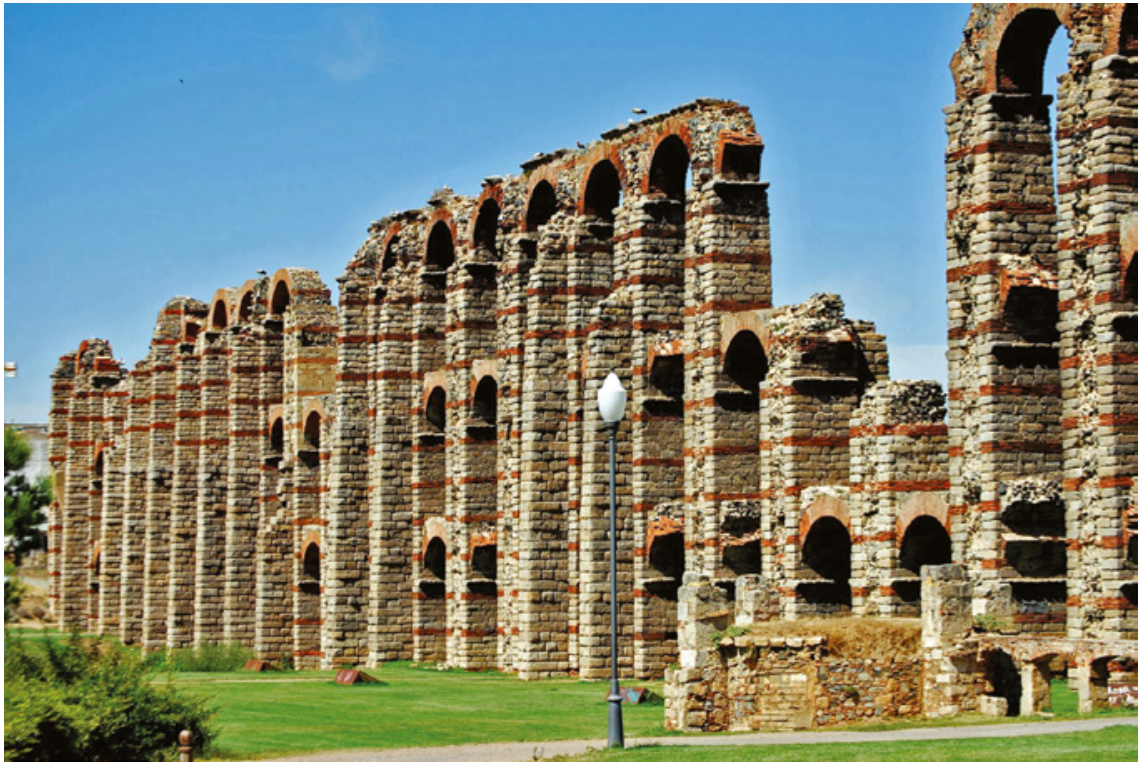

FIGURE 8.4 Acueducto de los Milagros, Mérida, España PHOTO MARLENE VD, BY CC BY-SA 3.0 ES 